\title{
The sexual status of Colebrookea (Labiatae)
}

\author{
G. Raza Bhatti and Martin J. Ingrouille
}

\begin{abstract}
Bhatti, G. Raza ${ }^{1}$ and Ingrouille, Martin J.2 ('Department of Botany, Shah Abdul Latif University, Khairpur (Mirs), Sindh, Pakistan; 'Biology Department, Birkbeck College, University of London, Malet Street, London, WC1E 7HX, United Kingdom) 1997. The sexual status of Colebrookea (Labiatae). Telopea 7(3): 221-225. The sexual status of Colebrookea Smith (Labiatae) has been investigated and found to be dioecious and sexually dimorphic. Male flowers have a small non-functioning ovary and long exserted stamens. Female flowers have small staminodes inserted inside the corolla, and a gynoecium in which only one mericarp matures. The corolla is smaller in female flowers and the calyx larger. The mericarp is released within the calyx. The fruiting calyx enlarges after pollination, with calyx lobes reduced to plumose teeth.
\end{abstract}

\section{Introduction}

Smith (1805) described a monotypic genus Colebrookea from Nepal, with the description of the species C. oppositifolia Smith, first collected by Dr Buchanan in 1802 from Nepal. It was described and named in honour of Henry Thomas Colebrooke Esq., Chief Judge of the Supreme Civil and Criminal Courts for the natives of Bengal, because of his interest in the history of the plants of that country. C. ternifolia Roxburgh from Mysore in India was later described (Roxburgh 1815) but subsequent authors have not regarded this as being sufficiently distinct to merit specific recognition.

Colebrookea is an isolated taxon with a chequered taxonomic history. For example, Poiret (1817) included Colebrookea as a synonym of Elsholtzia Willdenow. Colebrookea has been placed in various subfamilies or tribes: Menthoideae (Bentham 1830), Menthoideae, Mentheae (Endlicher 1838), Satureieae, Elsholtzieae (Bentham 1848), Satureieae, Origaninae (Bentham 1876) Lamioideae, Pogostemoneae (Briquet 1897). Press (1982) believed Colebrookea to be the most isolated of all the genera within the Pogostemoneae with Pogostemon and Elsholtzia as its nearest neighbours. Cantino, Harley and Wagstaff established a new subfamily, the Pogostemonoideae, to include Colebrookea, Pogostemon and a number of other genera which did not easily fit in the Lamioideae (Cantino 1992).

Despite this recent consensus that Colebrookea is close to Pogostemon it is clearly an isolated taxon with several distinct characteristics. It is superficially like Pogostemon plectranthoides Desf. and its close relatives, in being a semi-woody erect shrub, and is densely hairy on most parts with simple uniseriate hairs $0.5-1.2 \mathrm{~mm}$ long and having up to 8 cells. Branched hairs are found amongst simple hairs on the inflorescence. In addition the inflorescence consists of densely packed flowers in more than two verticillasters up to $100 \mathrm{~mm}$ long. However, the flowers are tiny, less than $2 \mathrm{~mm}$ in diameter, more similar in size to those herbaceous and semi-aquatic species of Pogostemon subgenus Dysophyllus (Blume) Bhatti \& Ingrouille. The flowers in Colebrookea are very different in shape from those of Pogostemon (Bhatti \& Ingrouille 1997). For example, the campanulate calyx enlarges in fruit to little more than $3 \mathrm{~mm}$ and the lobes are reduced to long plumose teeth. Importantly, unlike Pogostemon the stamens lack moniliform hairs on the filaments. 
One of the most interesting features of Colebrookea is its sexuality which is unusual for Labiatae. Most authors have not noted its sexuality. Briquet (1897) described it as gynodioecious but Gamble (1921) described it as functionally dioecious, a description followed by Cooke (1958: 541). Mathew (1982) and Hedge (1990) referred to the flowers as being 'unisexual' or 'often unisexual' respectively. In the following we report a detailed examination of the flowers.

\section{Materials and methods}

Specimens are listed in Table 1. Permanent slides of dissected corollas were made from dried specimens using DPX mountant without staining. Approximately 6 flowers from each specimen, from different parts of the verticillaster, were dissected. Drawings were made from images projected by a photographic enlarger. A scanning electron microscope (JEOL JSM 35CF) was used to study nutlet morphology. Air-dried samples were mounted on stubs and coated with gold using a EMITECH K550 Sputter coater for 8-12 minutes.

Table 1. Specimens examined:

\section{Male plants}

Forrest 9578 (K) CHINA, Yunnan (no date of collection indicated);

Forrest 12740 (K) CHINA, Yunnan (no exact locality and date of collection and name of collector mentioned); Henry 11593 CHINA, Yunnan (no exact locality and date of collection mentioned):

Gamble 24053 (K), INDIA, Dhera Dun, Jan 1893;

Drummond s.n. (K), INDIA, Punjab, (no exact locality indicated);

[collector unclear] 40 (K), PAKISTAN, Salt range, Hazara (no date of collection indicated);

Stewart 455 (K), PAKISTAN, Peshawar (no date of collection indicated)

\section{Female plants}

Drummond 20475, INDIA, Punjab, 1922, (K, neotype);

Bowen 620 (K), INDIA, U.P. Foot hills of the Himalayas between Rajpur and Mussorie, 24 Feb 1962 to 9 Mar 1962;

Rao 33038 (K), INDIA, Poona, Lonayla, 5 Mar 1962;

Hara et al. 6306445 (K), NEPAL, Phusri-Sanguri, Bhanjang-Dhera-Pani, 16 Oct 1963;

Henry 11593 B (K), CHINA, Yunnan (no exact locality and date of collection mentioned).

\section{Results and discussion}

Colebrookea is dioecious with dimorphic male and female flowers (Fig. 1). They differ in the following respects:

Male flowers: calyx a narrow skirt around base of corolla, c. $0.7 \mathrm{~mm}$ deep, $0.2-0.3 \mathrm{~mm}$ wide at base, 10-veined; outer surface with short simple uniseriate, 3-celled hairs c. $0.4 \mathrm{~mm}$ long. ; inner surface glabrous; lobes reduced to plumose teeth c. $0.5 \mathrm{~mm}$ long. Corolla is c. $1.7 \mathrm{~mm}$ long; lower lip orbicular, c. $0.7 \mathrm{~mm}$ in diameter with two lateral lobes; the upper lip emarginate or bilobed, $0.5 \times 1.5 \mathrm{~mm}$; staminal filaments inserted at height of $0.9 \mathrm{~mm}$ in tube. Stamens of equal length, c. $2 \mathrm{~mm}$ long, the exserted part c. $1.2 \mathrm{~mm}$. Style short, included in corolla tube, c. $1.4 \mathrm{~mm}$ long; stigma lobes $0.4-0.5 \mathrm{~mm}$. Ovary four-lobed; ovules abortive (does not form mature mericarps).

Female flowers: calyx at anthesis campanulate, $0.2-0.3 \mathrm{~mm}$ wide at base and $0.9 \mathrm{~mm}$ wide at throat, $0.5-0.7 \mathrm{~mm}$ deep; outer surface covered by simple hairs. At anthesis plumose teeth somewhat longer than the tube; elongating in fruiting calyx to $2.0-2.7 \mathrm{~mm}$ 


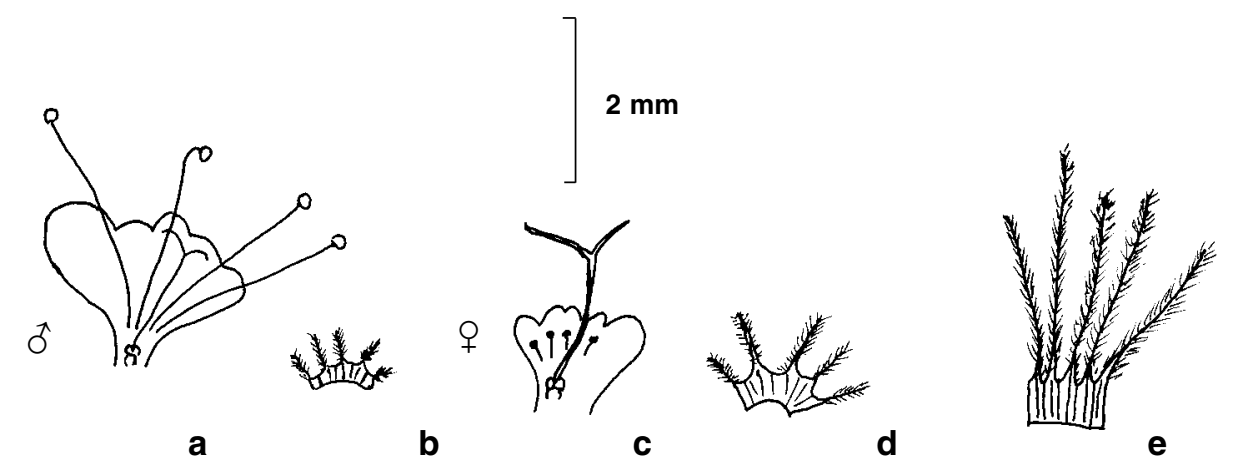

Fig. 1. Colebrookea Smith. a, b, male flower. a, corolla; b, calyx. c, d, e, female flower. c, corolla; $\mathbf{d}$, calyx; e, fruiting calyx. Scale bar $=2 \mathrm{~mm}$.

long (Fig. 2a). Corolla to $1.5 \mathrm{~mm}$ long with a similar shape but somewhat smaller than the corolla in the male flower; lower lip orbicular, c. $0.4 \mathrm{~mm}$ in diameter. Staminodes tiny with partly formed anthers only; included inside the corolla tube, filaments $0.2-0.4 \mathrm{~mm}$ long, inserted at height of $0.5 \mathrm{~mm}$ in the tube (Fig. 2b). Style is exserted, c. $1.5 \mathrm{~mm}$ long, stigma lobes $0.5-0.6 \mathrm{~mm}$. Ovary four-lobed; upper surface covered by simple unicellular hairs; single lobe maturing into a mericarp (others abortive); mericarp obovate, remaining inside the calyx for dispersal (Figure 2 c, d).

A modified calyx is commonly involved in mericarp dispersal in the Labiatae (Bouman \& Meeuse 1992). Mericarp release is delayed until after the dispersal of the calyx. Plumose calyces are only one of several kinds of modifications that have been observed in different genera.

Gynodioecy is particularly common in the Labiatae (East 1940, Lewis and Crowe 1964, García and Muñoz 1988). 56.7\% of all species studied have been judged to be gynodioecious and often there is variation in the ratio of hermaphrodite and female plants in different populations. Hermaphrodite flowers are commonly protandrous. Many workers have suggested that dioecy normally evolves from gynodioecy but despite the high prevalence of gynodioecy in the Labiatae, dioecy is uncommon. No trace of gynodioecy has been discovered in Colebrookea which is unequivocally dioecious.

Dioecious species of Labiatae normally have close relatives which have hermaphrodite flowers. In the genus Lepechinia Willd. (Hart 1985) different sections are either hermaphrodite and gynodioecious or gynodioecious and dioecious. In this genus dioecy has probably evolved more than once from gynodioecy. This contrasts with Nepeta L. where most species are hermaphrodite but those in section Oxynepeta are dioecious. Dioecy has probably evolved once in the latter group (Ubera \& Vadés 1983). The isolated position of Colebrookea provides few clues to the evolutionary origin of dioecy in it. However, it is interesting that Tetradenia, which was once considered an intermediate genus between Colebrookea and Elsholtzia Willd. by Bentham (1830), also has dioecious species. Tetradenia fruticosa Bentham was described as hermaphrodite (Bentham 1830) but Codd (1983) has shown that plants are dioecious. Like Colebrookea male plants have flowers with fertile stamens and a small non-functioning pistil. However dioecy is clear because female plants have flowers which lack either stamens or staminodes. A different species T. barberae (N.E. Br.) Codd is marginally gynodioecious (Codd 1984). 
In some dioecious species of Labiatae the flowers are normally small and, as in Lepechinia and Colebrookea, the female flowers have larger calyces and smaller corollas than male flowers. A wide ranging study of the relationship between dioecy, male/female allocation, pollinator reward/showiness and dispersal syndrome in Labiatae, to identify the circumstances in which dioecy is selected, would provide interesting results.

\section{Acknowledgments}

We would like to thank the staff of the Royal Botanic Gardens, Kew (K) and Natural History Museum (BM) herbaria and libraries for their cooperation in providing facilities. Thanks also to Gohar Soomro for printing the SEM photographs.

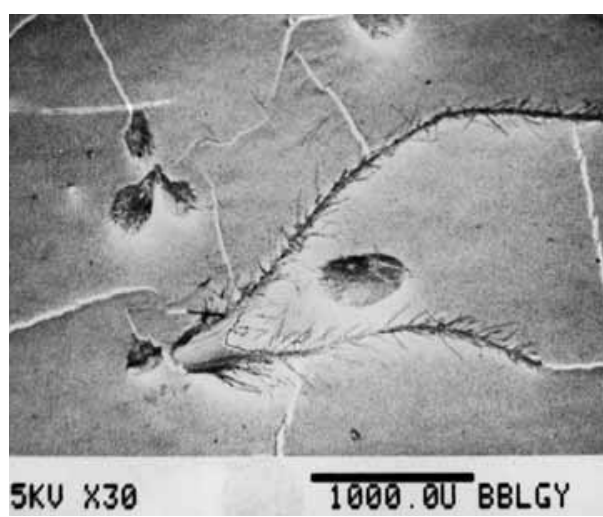

a

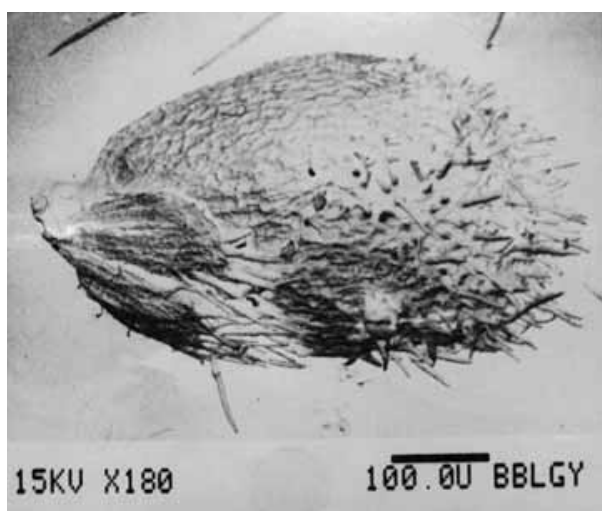

C

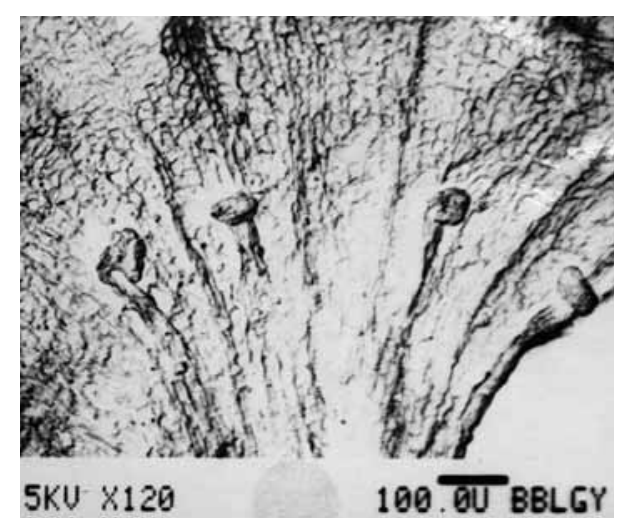

b

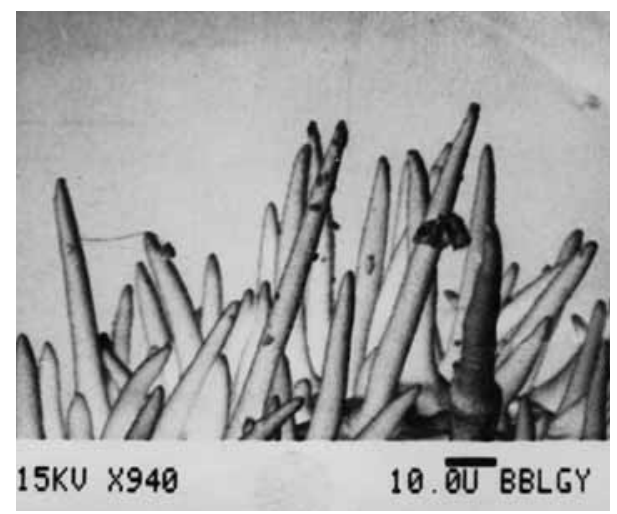

d

Fig. 2. Scanning electron micrographs. a, fruiting calyx of female flowers showing very long plumose teeth; $\mathbf{b}$, insertion of staminodes within corolla of female flower showing reduced size; c, solitary mature nutlet showing shape; $\mathbf{d}$, unicellular hairs on distal portion of nutlet. Scales (in $\mu \mathrm{m}$ ) as indicated on micrographs. 


\section{References}

Bentham, G. (1830) Synopsis of the genera and species of Indian Labiatae enumerated in the catalogue of the collection in Dr. Wallich's charge. Plantae Asiaticae Rariores 1: 28-31.

Bentham, G. (1832-36) Labiatarum Genera et Species. (Ridgeway and Sons: London).

Bentham, G. (1848) Labiatae. Pp. 27-603 in A. de Candolle (ed.), Prodromus Systematis Naturalis Regni Vegetabilis, vol. 12. (Treuttel and Wurtz: Paris).

Bentham, G. (1876) Labiatae. Pp. 1160-1223 in G. Bentham and J. D. Hooker (eds), Genera Plantarum, vol. 2. (Reeve and Co.: London).

Bhatti, G. R. (1995) Systematics of Pogostemon Desf. (Labiatae) and related genera. (Unpublished Ph.D. Thesis, Birkbeck College, University of London).

Bhatti, G. R. and Ingrouille, M. J. (1977) Systematics of Pogostemon (Labiatae). Bull. nat. Hist. Mus. Lond. (Bot.) 27(2): 77-148.

Bouman, F. and Meeuse, A. D. J. (1992) Dispersal in Labiatae. Pp. 193-202 in R.M. Harley and T. Reynolds (eds), Advances in Labiatae Science. (Royal Botanic Gardens: Kew).

Briquet, J. (1897) Labiatae, Stachyoideae-Pogostemoneae. Pp. 326-331 in A. Engler \& K. Prantl (eds.), Die natürlichen Pflanzenfamilien ed. 1, vol. 4, part 3a. (Wilhelm Engelmann: Leipzig).

Cantino, P. D. (1992) Toward a phylogenetic classification of the Labiatae. Pp. 27-37 in R.M. Harley and T. Reynolds (eds), Advances in Labiatae Science. (Royal Botanic Gardens: Kew).

Codd, L. E. (1983) The genus Tetradenia Benth. (Lamiaceae). I. African species. Bothalia 14(2): 177-183.

Codd, L. E. (1984) The genus Tetradenia Benth. (Lamiaceae). II. Malagassy Republic. Bothalia 15: 1-6.

Cooke, T. (1958) The Flora of the Presidency of Bombay, vol. 2. (Reprint, Botanical Survey of India: Calcutta).

East, E. M. (1940) The distribution of self-sterility in the flowering plants. Proc. Amer. Philos. Soc. 82 (4): 449-518.

Endlicher, S.L. (1838). Labiatae. Genera Plantarum, part 8: 607-632. (Fr. Beck: Vindobonae).

Gamble, J. S. (1921) Flora of the Presidency of Madras, vol. 2 (Adlard: London).

García Montoya, F. and Muñoz Álvarez, J. M. (1988) Ginodioecia en Teucrium fruticans L. comparación entre formas MF y MS. Lagascalia 15 (suppl.): 691-696.

Hart, J. A. (1985) Evolution of dioecism in Lepechinia Willd. sect. Parviflorae (Lamiaceae). Syst. Bot. 10: $147-154$.

Hedge, I. C. (1990) Labiatae. Flora of Pakistan, No. 92.

Lewis, D. and Crowe, I. K. (1964) The genetics and evolution of gynodioecy. Evolution 10: 115-125.

Mathew, K. M. (1982) The Flora of Tamilnadu Carnatic 2: 1253-1254.

Poiret, J.L.M. (1817) Elshotzia. Suppl. 5 to J.B.A.P.M. Lamarck, Encyclopédie Méthodique Botanique.

Press, J.R. (1982) Taxonomic studies in the Labiatae tribe Pogostemoneae. Bull. Brit. Mus. (Nat. Hist.), Bot. 10 (1): 1-89.

Roxburgh, W. (1815) Plants of the Coast of Coromandel, vol. 3. (W. Bulmer: London).

Smith, J. E. (1805) Exotic Botany, vol. 2. (R. Taylor: London).

Ubera, J. L. and Vadés, B. (1983) Revisión del género Nepeta (Labiatae) en la península Iberica e Islas Baleares. Lagascalia 12 (1) 3-80. 
